Part of Journal of Research of the National Bureau of Standards, Volume 30, January 1943

\title{
THERMAL EXPANSION OF SOME BRONZES
}

\author{
By Peter Hidnert
}

\section{ABSTRACT}

The results obtained in the course of independent tests and investigations on the linear thermal expansion of four groups of bronzes designated as tin-zinc, leaded, aluminum, and silicon bronzes are given for different temperature ranges. Curves showing the typical expansion and contraction characteristics of these bronzes during heating and cooling are presented. Ternary diagrams are given to show the effect of composition on the coefficients of expansion of copper-tin-zinc and copper-tin-lead alloys. In general, the coefficients of expansion of these copper-base alloys increase as the addition of tin, zinc, or lead is increased. For the range from $20^{\circ}$ to $100^{\circ} \mathrm{C}$, the average coefficients of expansion of the various bronzes were found to be between $16.8 \times 10^{-6}$ and $19.0 \times 10^{-6} /{ }^{\circ} \mathrm{C}$.

\section{CONTENTS}

I. Introduction 19 Page

II. Materials investigated

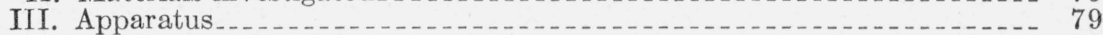

IV. Results and discussion

V. References

\section{INTRODUCTION}

During the past 30 years, data on the linear thermal expansion of copper-base alloys designated as tin-zinc, leaded, aluminum, and silicon bronzes have been obtained at the National Bureau of Standards. These results are based on independent tests and investigations, the specific purposes of which in general were not related. Therefore, the ranges of temperature within which the bronzes were investigated differed in many cases. These data, together with some previously published results, are summarized in this paper. Ternary diagrams showing the effect of composition on the coefficients of expansion of copper-tin-zinc and copper-tin-lead alloys are given.

Available data from previous investigators on the linear thermal expansion of various bronzes of known compositions are given in table $1{ }^{1}$ Some of the results in this table, in combination with data of the present paper, were used in the preparation of the ternary diagrams.

1 Data (not listed in table 1) from 2 manufacturers have been published by N. L. Mochel, Thermal Expansion of Metals, Symposium on Effect of Temperature on the Properties of Metals, Am. Soc. Testing Materials and Am. Soc. Mech. Engrs., p. 683 (1931). 
TABLE 1.-Previously published values of coefficients of linear thermal expansion of bronzes by previous observers

\begin{tabular}{|c|c|c|c|c|c|c|c|c|c|c|c|c|c|c|c|}
\hline \multirow[b]{2}{*}{ Observer } & \multirow[b]{2}{*}{ Date } & \multirow[b]{2}{*}{ Material } & \multicolumn{6}{|c|}{ Chemical composition } & \multirow[b]{2}{*}{ Treatment } & \multicolumn{6}{|c|}{ A verage coefficients of expansion per degree centigrade } \\
\hline & & & $\mathrm{Cu}$ & Sn & $\mathrm{Zn}$ & $\mathrm{Pb}$ & $\mathrm{Ni}$ & $\mathbf{P}$ & & $\begin{array}{l}0^{\circ} \text { to } \\
80^{\circ} \mathrm{C}\end{array}$ & $\begin{array}{l}20^{\circ} \text { to } \\
100^{\circ} \mathrm{C}\end{array}$ & $\begin{array}{l}20^{\circ} \text { to } \\
200^{\circ} \mathrm{C}\end{array}$ & $\begin{array}{l}20^{\circ} \text { to } \\
300^{\circ} \mathrm{C}\end{array}$ & $\begin{array}{l}20^{\circ} \text { to } \\
400^{\circ} \mathrm{C}\end{array}$ & Other range \\
\hline \multirow{2}{*}{ Fizeau $[1]$... } & \multirow{2}{*}{1869} & \multirow{2}{*}{$\begin{array}{l}\text { Bronze } \\
\text { Bronze }\end{array}$} & \multirow{8}{*}{\begin{tabular}{l}
\multicolumn{1}{c}{$\%$} \\
86.3 \\
81.20 \\
81.20 \\
97.6 \\
97.6 \\
94.6 \\
94.6 \\
90 \\
80 \\
70 \\
90 \\
84.1
\end{tabular}} & \multirow{7}{*}{$\begin{array}{c}\% \\
9.7 \\
9.87 \\
9.87 \\
2.2 \\
2.2 \\
4.7 \\
4.7 \\
10 \\
20 \\
30\end{array}$} & \multirow{3}{*}{ 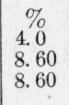 } & $\%$ & $\%$ & $\%$ & & \multirow{5}{*}{\begin{tabular}{|c|}
$\times 10^{-6}$ \\
a17.8 \\
17.9 \\
18.0 \\
17.0 \\
17.0 \\
17.4 \\
17.4
\end{tabular}} & $\times 10^{-6}$ & $\times 10^{-6}$ & $\times 10^{-6}$ & $\times 10^{-6}$ & $\times 10^{-6}$ \\
\hline & & & & & & 0.17 & & - & & & & & & & \\
\hline Benoit b $[2]_{-}$ & 1889 & Phosphor bronze & & & & & & 0.2 & Hardened & & & & & & \\
\hline & & do do & & & & & & $\begin{array}{l}.2 \\
.7 \\
7\end{array}$ & Annealed & & & & & & \\
\hline \multirow{3}{*}{ Le Chatelier [14] ....... } & \multirow{3}{*}{1889} & Bronze... & & & & & & & $\begin{array}{l}\text { Annealed_ } \\
\text { do }\end{array}$ & & & & & & $22.0\left(0^{\circ}\right.$ to $\left.900^{\circ} \mathrm{C}\right)$ \\
\hline & & $\left\{\begin{array}{l}-1 \text { do } \\
\hdashline \text { do }\end{array}\right.$ & & & $-\cdots$ & & & & _..... do do & & & & & & $\begin{array}{l}27.0\left(0^{\circ} \text { to } 800^{\circ} \mathrm{C}\right) \\
29.5\left(0^{\circ} \text { to } 700^{\circ} \mathrm{C}\right)\end{array}$ \\
\hline & & Aluminum bronze ${ }^{\circ}$ & & & & & & & - nd & & & & & & $23.0\left(0^{\circ}\right.$ to $\left.900^{\circ} \mathrm{C}\right)$ \\
\hline $\begin{array}{l}\text { Dittenberger and } \\
\text { Gehrcke b [3]. }\end{array}$ & 1902 & Bronze & & 6.2 & 8.7 & .7 & & ...- & -........... & $\ldots$ & & - & d 18.1 & e 18.7 & f 19.2 \\
\hline Henning g [4] & 1907 & do & 84 & 6 & 9 & & & & & & & & h 18.2 & i 18.7 & j 19.3 \\
\hline \multirow{5}{*}{ Bein b $[5]$} & \multirow{5}{*}{1912} & Bronze ${ }^{k}$ & $\begin{array}{l}96 \\
93.5\end{array}$ & $\begin{array}{l}2.6 \\
6.5\end{array}$ & 0.45 & & & (n.... & 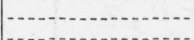 & 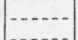 & $\begin{array}{l}17.2 \\
17.5\end{array}$ & & (n........ & & \\
\hline & & Phosphor bronze $\mathrm{m}$ & 95.40 & 4. 25 & 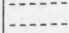 & (n.... & -... & .37 & Cast & & 17.4 & 17.8 & 18.2 & & \\
\hline & & Chain bronze m & $\begin{array}{l}95.40 \\
94.86\end{array}$ & $\begin{array}{l}4.25 \\
4.88\end{array}$ & $\cdots$ & - & & $\begin{array}{l}.37 \\
.12\end{array}$ & Cold-rolled & $\cdots$ & 17. 2 & 17. 6 & 18.0 & $a \ldots$ & $\cdots$ \\
\hline & & do & 94.86 & $\begin{array}{l}4.80 \\
4.88\end{array}$ & $\cdots$ & $\cdots$ & & .12 & Cold-rolled- & - & 17.1 & 17.4 & 17.8 & & $-\cdots$ \\
\hline & & Bronze $\mathrm{m}$ & 92.04 & 7. 67 & ....... & . & (n) & .11 & Cast & ......... & 17.5 & 17.9 & 18.2 & 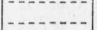 & $\cdots$ \\
\hline \multirow{3}{*}{ Hidnert b $[6] \ldots$} & \multirow{3}{*}{1921} & do do & $\begin{array}{l}92.04 \\
89.69\end{array}$ & $\begin{array}{r}7.67 \\
10.14\end{array}$ & $-\cdots$ & $\cdots$ & 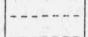 & $\begin{array}{r}.11 \\
00\end{array}$ & $\begin{array}{l}\text { Cold-rolled } \\
\text { Cast }\end{array}$ & (n)..... & $\begin{array}{l}17.3 \\
17.7\end{array}$ & $\begin{array}{l}17 \\
18\end{array}$ & 18.2 & & $-1+2-10-10-1$ \\
\hline & & do & $\begin{array}{l}89.09 \\
89.69\end{array}$ & 10.14 & (n...- & -..... & & .00 & Cold-rolled & ...... & 17.6 & 17. & $\begin{array}{l}18.0 \\
18.3\end{array}$ & & $-\cdots$ \\
\hline & & Aluminum bronze ${ }^{n}$ & $\begin{array}{l}92.17 \\
92.17\end{array}$ & (-n... & $\begin{array}{l}.40 \\
.40\end{array}$ & & $\begin{array}{c}\text { Trace } \\
- \text { do }\end{array}$ & & $\begin{array}{l}\text { Hot-rolled } \\
\text { Hot-rolled and }\end{array}$ & & $\begin{array}{l}16.5 \\
16.6\end{array}$ & $\begin{array}{l}17.3 \\
17.2\end{array}$ & $\begin{array}{l}18.2 \\
17.8\end{array}$ & & \\
\hline Hidnert [7] & 1932 & (Bronze o & $\begin{array}{l}\text { 84. } 84 \\
85.0\end{array}$ & $\begin{array}{c}\text { 14. } 95 \\
5.0\end{array}$ & 5.1 & $\begin{array}{l}.21 \\
4.9\end{array}$ & & & Cast & & $\begin{array}{l}\text { 18. } 0 \\
17.8\end{array}$ & $\begin{array}{l}18.2 \\
18.1\end{array}$ & $\begin{array}{l}18.6 \\
18.5\end{array}$ & $\begin{array}{l}18.8 \\
18.9\end{array}$ & $\begin{array}{l}\text { 19. } 3\left(20^{\circ} \text { to } 500^{\circ} \mathrm{C}\right) \\
19.3\left(20^{\circ} \text { to } 500^{\circ} \mathrm{C}\right)\end{array}$ \\
\hline Wilkins $[8]$.- & 1933 & Silicon bronze $q_{-}$ & 94.75 & 0.5 & 1.5 & & & & & & r 17.0 & & & & \\
\hline
\end{tabular}




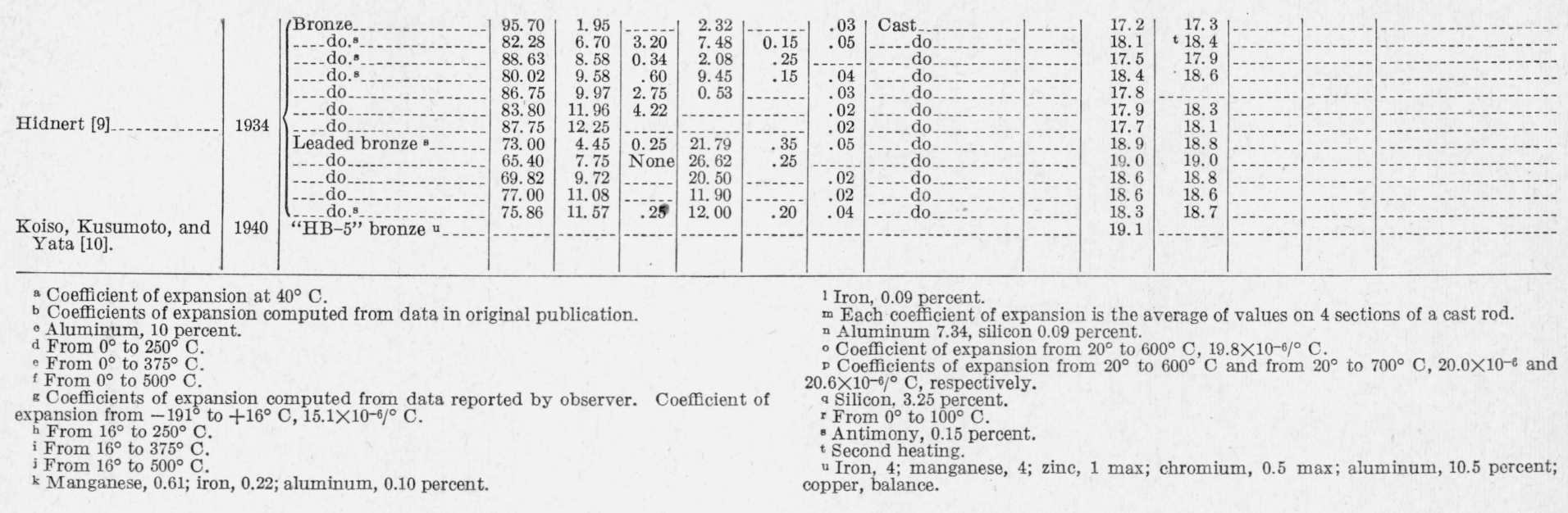




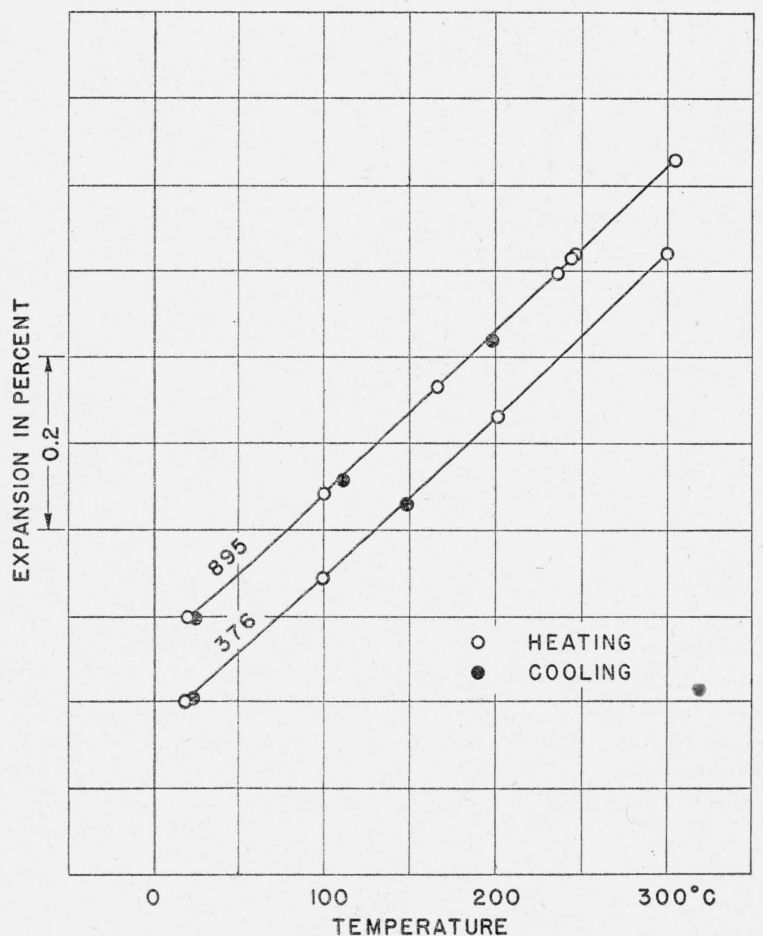

FIGURE 1.-Linear thermal expansion of two cast tin-zinc bronzes.

Sample 376: copper 88, tin 8, zinc 4 percent; sample 895: copper 86.5, tin 11, zine 2.5, maximum impurities 0.2 percent. 


\section{MATERIALS INVESTIGATED}

The samples of bronzes were provided by the American Brass Co., Waterbury, Conn., American Bronze Corporation (now American Non-Gran Bronze Corporation), Berwyn, Pa., Bridgeport Brass Co., Bridgeport, Conn., E. I. du Pont de Nemours \& Co., Inc., Wilmington, Del., Fredericksen Co. (now Saginaw Bearing Co.), Saginaw, Mich., National Bureau of Standards, Titanium Alloy Mfg. Co., Niagara Falls, N. Y., and W. \& L. E. Gurley, Troy, N. Y. The chemical compositions and available information regarding the treatments of the samples are given in table 2. Most of the values for chemical composition were furnished by the manufacturers.

The length of each sample used in the determinations of linear thermal expansion was $300 \mathrm{~mm}$ (11.8 in). The cross sections of all samples except those designated as 38 and 39 were circular, with diameters of 8 to $13 \mathrm{~mm}$ (0.31 to 0.51 in). The diameter in each case was the same as that of the "as received" rod. Samples 38 and 39 , machined to $5 \mathrm{~mm}$ (0.20 in.) square section, were cut from bars having a section $16 \mathrm{~mm}$ (0.63 in.) square.

\section{APPARATUS}

The types of precision micrometric thermal-expansion apparatus used for determining the linear thermal expansion of the bronzes are described in previous publications $[11,12,6,13] .{ }^{2}$ In addition to the differences in design, the instruments differed in the ranges of temperature over which they could be operated. However, essentially the same results have been obtained with each of the instruments used for the same ranges of temperature.

\section{RESULTS AND DISCUSSION}

Typical expansion and contraction curves for four groups of bronzes are shown in figures 1 to 4 . These figures indicate that for a relatively narrow range of temperature (fig. 1) the expansion and contraction curves nearly coincide, but in cases involving wider ranges of temperature (figs. 2 to 4 ) the expansion and contraction curves diverge appreciably. It is of interest to note that the expansion curves in figure 3 indicate that a marked decrease in the rate of expansion occurred in the hard-drawn aluminum bronzes at temperatures between $700^{\circ}$ and $800^{\circ} \mathrm{C}$. On the other hand, the curves for both the harddrawn and annealed silicon bronzes (fig. 4) showed a marked increase in the rate of expansion between $900^{\circ}$ and $1,000^{\circ} \mathrm{C}$.

The average coefficients of expansion of the four groups of bronzes, computed from the expansion and contraction curves (typified by figs. 1 to 4 ), are given in table 2 for temperature ranges within which observations were made. The differences in length of most of the bronzes before heating and after passing through the heating and cooling cycle are also shown in this table. In general, the aluminum and silicon bronzes (figs. 3 and 4, and table 2) were investigated over wider ranges of temperature than the tin-zinc and leaded bronzes (figs. 1 and 2, and table 2).

\footnotetext{
${ }_{2}$ Figures in brackets indicate the literature references at the end of this paper.
} $497911-43-6$ 


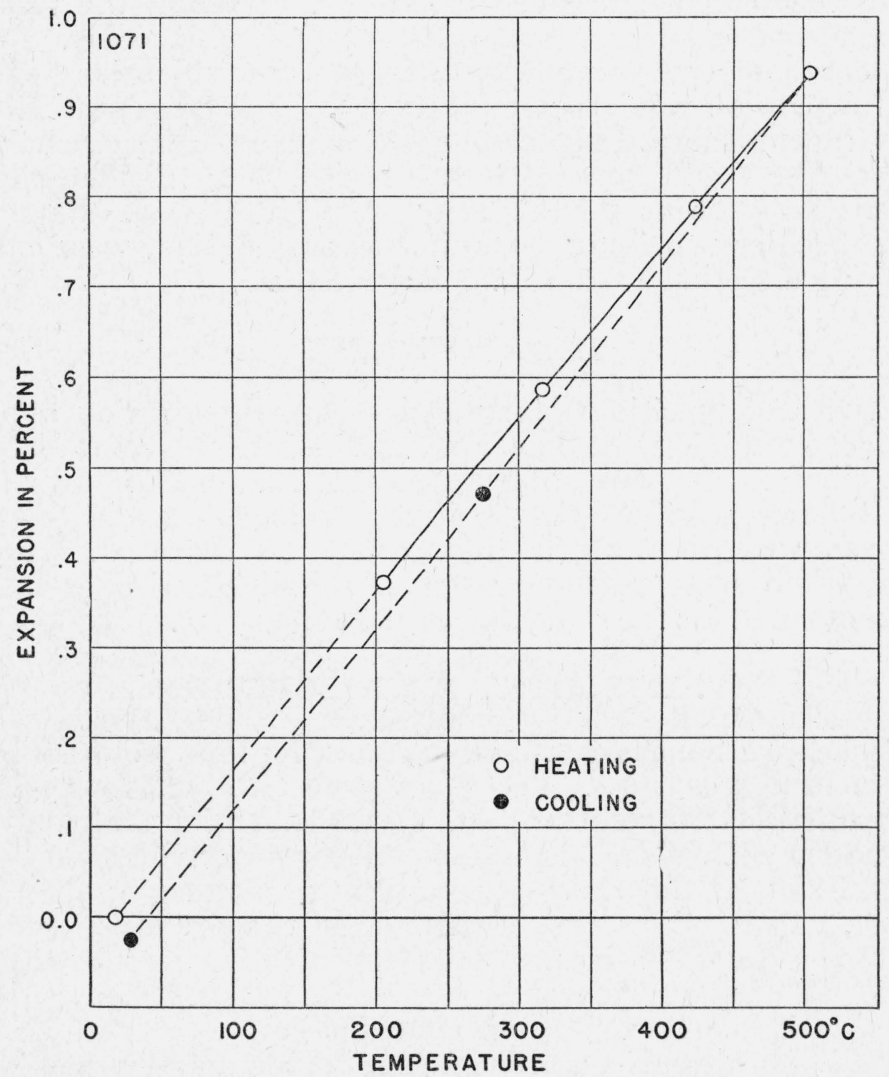

FIGURE 2.-Linear thermal expansion of leaded bronze (treatment unknown). Sample 1071: copper 70, tin 9, lead 21, maximum impurities 0.2 percent. 


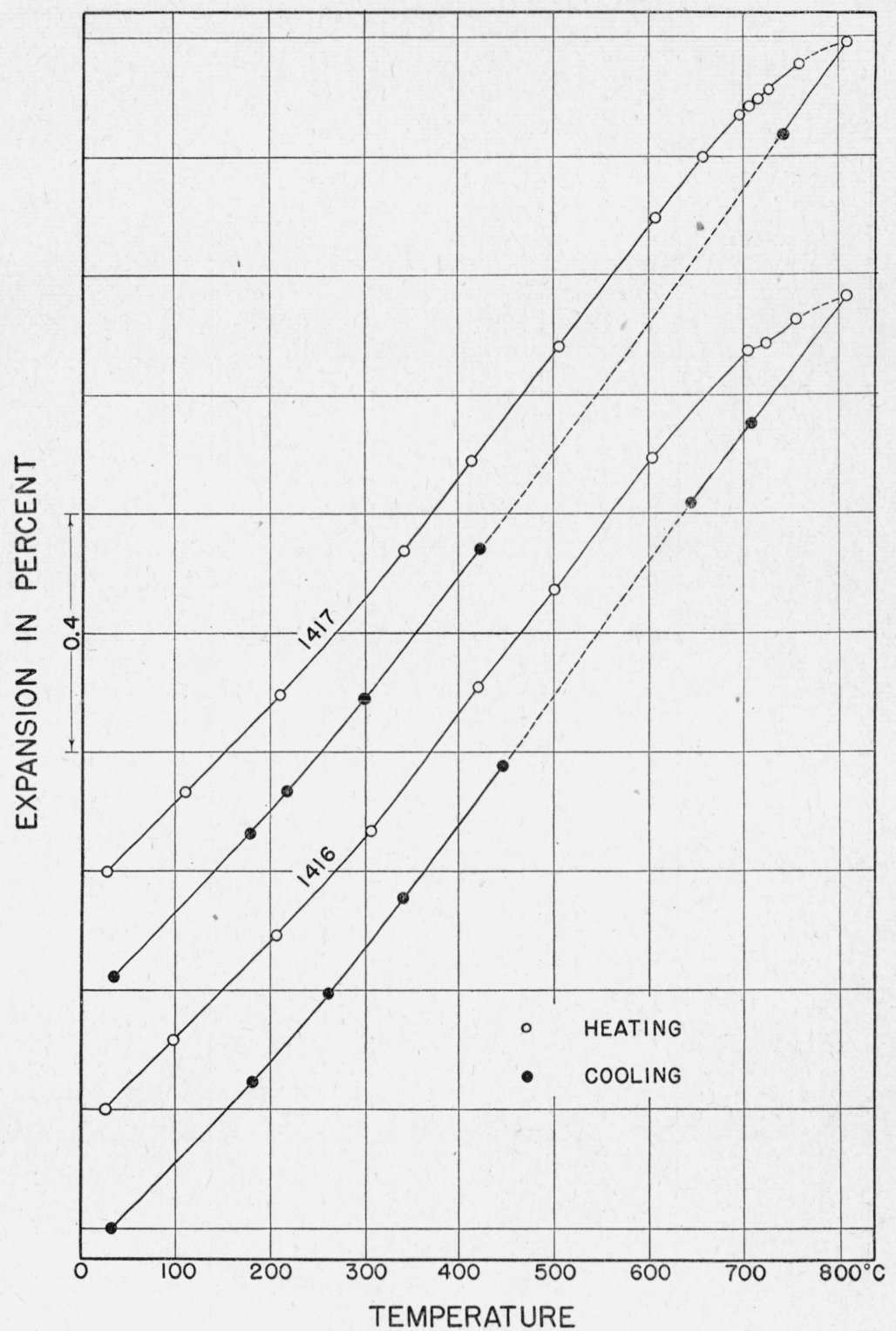

FIGURE 3.-Linear thermal expansion of two hard-drawn aluminum bronzes.

Sample 1416: copper 89.71, tin 0.38, aluminum 9.29, iron 0.44 percent; sample 1417: copper 89.43, tin 0.33, aluminum 9.30 , iron 0.58 percent. 
TABLE 2.-Coefficients of linear expansion of four groups of bronzes

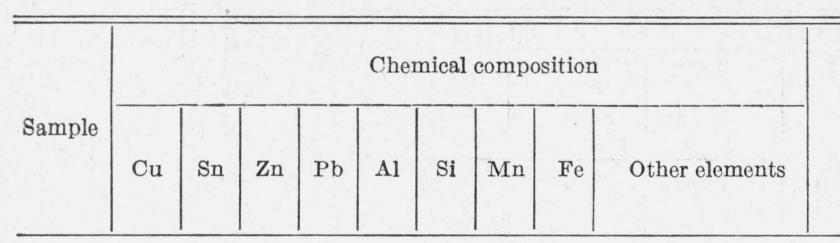

A. TIN-ZINC BRONZES

\begin{tabular}{|c|c|c|c|c|c|c|c|c|c|c|c|c|c|c|c|c|c|c|c|c|c|c|}
\hline $1105 \ldots$ & $\begin{array}{c}\% \\
98.6\end{array}$ & $\begin{array}{l}\% \\
1.3\end{array}$ & $\%$ & $\%$ & $\%$ & $\%$ & $\%$ & $\begin{array}{c}\% \\
0.02\end{array}$ & $\%$ & Hot-rolled and an- & $\begin{array}{c}\times 10^{-6} \\
16.8\end{array}$ & $\begin{array}{c}\times 10^{-6} \\
16.8\end{array}$ & $\left|\times 10^{-6}\right|$ & $\times 10^{-9}$ & $\times 10^{-8}$ & $\times 10^{-6}$ & $\times 10^{-6}$ & $\times 10^{-6}$ & $\times 10^{-6}$ & $\times 10^{-6}$ & $\times 10^{-6}$ & $\begin{array}{c}\% \\
-0.002\end{array}$ \\
\hline 84. & 90 & 6.5 & 2.0 & 1.5 & & & & & & $\begin{array}{l}\text { nealed. } \\
\text { Not known }\end{array}$ & •17. 4 & 17.8 & & & & & & & & & & \\
\hline $\begin{array}{l}308 \\
376\end{array}$ & $\begin{array}{l}88 \\
88\end{array}$ & & $\begin{array}{l}2 \\
4\end{array}$ & - & $\cdots$ & -1 & -... & $\cdots$ & & Cast & ...... & 17.8 & 18. 1 & 18. 5 & 18.8 & & & & & & & $\begin{array}{l}-.018 \\
-.004\end{array}$ \\
\hline $1068 \ldots$ & 87 & 7 & 5 & 1 & -...- & $\cdots$ & .... & -... & & Cast at $2,250^{\circ} \mathrm{F}$ & $\mathrm{d} 17.8$ & 17.8 & 18.1 & 18.5 & & & & & & & & +.001 \\
\hline $\begin{array}{l}38 \ldots \ldots \\
39\end{array}$ & \} 86.7 & 11.2 & 2.1 & & & & & & & $\begin{array}{l}\text { Cast and annealed } \\
\text { at } 745^{\circ} \mathrm{C}\left(1,373^{\circ} \mathrm{F}\right) \text {. }\end{array}$ & $\left\{\begin{array}{l}\mathrm{c} 17.6 \\
\mathrm{e} 17.6\end{array}\right.$ & $\begin{array}{l}\text { c17.8 } \\
\text {-17.9 }\end{array}$ & $\begin{array}{l}\mathrm{e} 18.0 \\
\mathrm{e} 18.1\end{array}$ & & & & & & & & & - \\
\hline $\begin{array}{l}894 \ldots \\
895 \ldots\end{array}$ & 86.5 & 11 & 2.5 & & & & & & $\left\{\begin{array}{l}\text { Maximum impur- } \\
\text { ities 0.2. }\end{array}\right.$ & $\left\{\begin{array}{l}\text { Cast in green sand } \\
\text { mold at about } \\
2,250^{\circ} \text { F. }\end{array}\right.$ & \} & $\begin{array}{l}\text { 18. } 1 \\
17.9\end{array}$ & $\begin{array}{l}18.3 \\
18.5\end{array}$ & $\begin{array}{l}18.7 \\
18.6\end{array}$ & & & & & & & & $\begin{array}{r}.000 \\
-.001\end{array}$ \\
\hline
\end{tabular}

\section{B. LEADED BRONZES :}

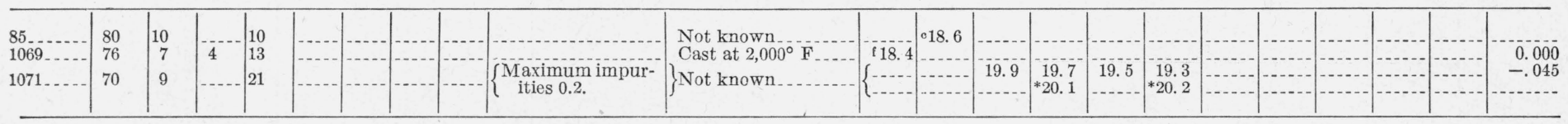

\section{ALUMINUM BRONZES a}

\begin{tabular}{|c|c|c|c|c|c|c|c|c|c|c|c|c|c|c|c|c|c|c|c|}
\hline $86 \ldots . . .$. & 90 & & & 10. & & & & Not known & •17. 1 & & & & & & & & & & \\
\hline $1416 \ldots$ & 89.71 & 0.38 & 0.00 & 9.29 & & 0.44 & & $\left\{\begin{array}{c}\text { Hard-drawn from } \\
716 \text { to } 3 / 8 \text { in. in } \\
\text { diameter. }\end{array}\right.$ & $\left\{\begin{array}{l}16.2 \\
-\end{array}\right.$ & $\begin{array}{r}16.3 \\
* 16.9\end{array}$ & $\begin{array}{r}16.8 \\
{ }^{*} 17.7\end{array}$ & $\begin{array}{r}17.9 \\
* 18.6\end{array}$ & 18.5 & $\begin{array}{r}19.0 \\
* 19.8\end{array}$ & $\begin{array}{r}18.9 \\
* 20.1\end{array}$ & ${ }^{*} 20.3$ & & & -0.21 \\
\hline 1417 & 89.43 & .33 & .00 & - 9.30 & & .58 & Nickel 0.36_- & $\left\{\begin{array}{c}\text { Hard-drawn from } \\
7 / 16 \text { to } 38 \text { in. in } \\
\text { diameter. }\end{array}\right.$ & $\left\{\begin{array}{l}16.2 \\
--\cdots\end{array}\right.$ & $\begin{array}{l}16.4 \\
* 17.1\end{array}$ & $\begin{array}{r}17.0 \\
* 17.9\end{array}$ & $\begin{array}{r}18.0 \\
* 18.6\end{array}$ & 18.6 & $\begin{array}{c}19.1 \\
\end{array}$ & $\begin{array}{l}\mathrm{g} 19.2 \\
* 20.0\end{array}$ & ${ }^{*} 20.4$ & & & -.19 \\
\hline
\end{tabular}




\begin{tabular}{|c|c|c|c|c|c|c|c|c|c|c|c|c|c|c|c|c|c|c|c|c|c|c|}
\hline \multirow[b]{2}{*}{ Sample } & \multicolumn{9}{|c|}{ Chemical composition } & \multirow{2}{*}{ Treatment } & \multicolumn{11}{|c|}{$\begin{array}{c}\text { Average coefficients of expansion (and contractiona) per degree } \\
\text { centigrade }\end{array}$} & \multirow{2}{*}{$\begin{array}{l}\text { Change } \\
\text { in } \\
\text { length } \\
\text { of sam- } \\
\text { ple after } \\
\text { heating } \\
\text { and } \\
\text { cooling }\end{array}$} \\
\hline & $\mathrm{Cu}$ & Sn & $\mathrm{Zn}$ & $\mathrm{Pb}$ & $\mathrm{Al}$ & $\mathrm{Si}$ & Mn & $\mathrm{Fe}$ & Other elements & & $\begin{array}{c}20^{\circ} \\
\text { to } \\
50^{\circ} \\
\mathrm{C}\end{array}$ & $\begin{array}{c}20^{\circ} \\
\text { to } \\
100^{\circ} \\
\mathrm{C}\end{array}$ & $\begin{array}{c}20^{\circ} \\
\text { to } \\
200^{\circ} \\
\mathrm{C}\end{array}$ & $\begin{array}{c}20^{\circ} \\
\text { to } \\
300^{\circ} \\
\mathrm{C}\end{array}$ & $\begin{array}{c}20^{\circ} \\
\text { to } \\
400^{\circ} \\
\mathrm{C}\end{array}$ & $\begin{array}{c}20^{\circ} \\
\text { to } \\
500^{\circ} \\
\mathrm{C}\end{array}$ & $\begin{array}{c}20^{\circ} \\
\text { to } \\
600^{\circ} \\
\mathrm{C}\end{array}$ & $\begin{array}{c}20^{\circ} \\
\text { to } \\
700^{\circ} \\
\mathrm{C}\end{array}$ & $\begin{array}{c}20^{\circ} \\
\text { to } \\
800^{\circ} \\
\mathrm{C}\end{array}$ & $\begin{array}{c}20^{\circ} \\
\text { to } \\
900^{\circ} \\
\mathrm{C}\end{array}$ & $\mid \begin{array}{c}900^{\circ} \\
\text { to } \\
1000^{\circ} \\
\mathrm{C}\end{array}$ & \\
\hline
\end{tabular}

D. SILICON BRONZES \&

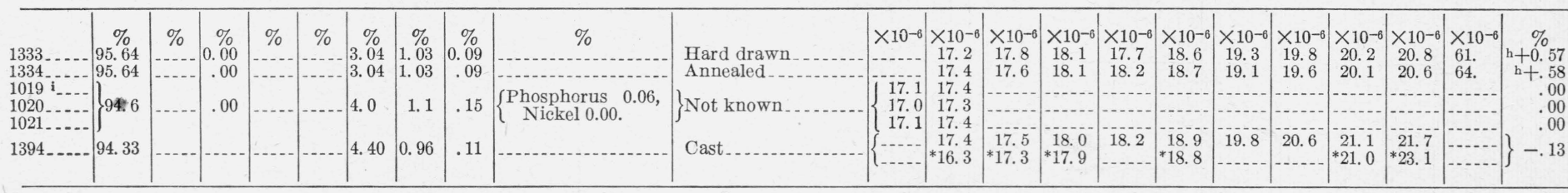

a Coefficients of contraction on cooling are indicated by asterisks.

${ }^{f}$ From $20^{\circ}$ to $40^{\circ} \mathrm{C}$. Coefficients of expansion per degree centigrade from $-20^{\circ}$ b Determined from the expansion curve on heating and the contraction curve on cooling. The plus sign indicates an increase in length c Determined by A. W. Gray, formerly of the National Bureau of Standards. d From $20^{\circ}$ to $40^{\circ} \mathrm{C}$. Coefficients of expansion per degree centigrade from $-20^{\circ}$ to $0^{\circ}, 0^{\circ}$ to $+20^{\circ}$, and $0^{\circ}$ to $+40^{\circ} \mathrm{C}$ were found to be $17.0 \times 10^{-6}, 17.0 \times 10^{-6}$, and $17.4 \times 10^{-6}$,

r From $20^{\circ}$ to $150^{\circ} \mathrm{C}$, determined by A. W. Gray. to $0^{\circ}, 0^{\circ}$ to $+20^{\circ}$, and $0^{\circ}$ to $+40^{\circ} \mathrm{C}$ were found to be $17.1 \times 10^{-6}, 18.1 \times 10^{-6}$, and $18.2 \times 10^{-6}$, g From $20^{\circ}$ to $650^{\circ} \mathrm{C}$

h Change in length determined from length measurements on a duplicate sample before and after heating it to $1,000^{\circ} \mathrm{C}$ and cooling to $20^{\circ} \mathrm{C}$. i Chemical composition determined by G. F. Commisa, of the National Bureau of Standards. 


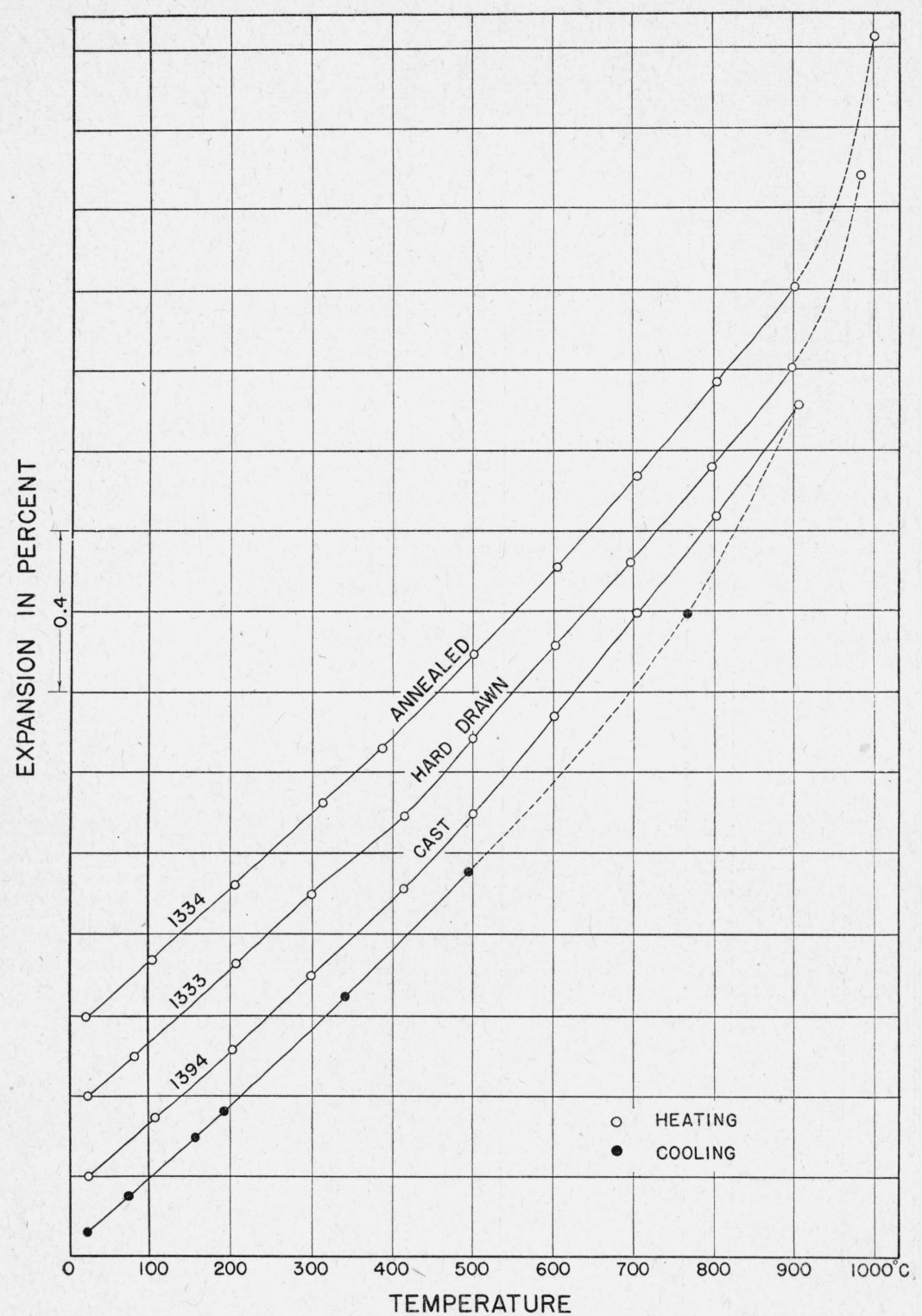

FIGURE 4.-Linear thermal expansion of three silicon bronzes.

Sample 1394: copper 94.33, silicon 4.40, manganese 0.96, iron 0.11 percent; samples 1333 and 1334: copper 95.64, silicon 3.04 , manganese 1.03 , iron 0.09 percent. 
The ternary diagrams in figure 5 show the influence of additions of tin and zinc on the coefficients of expansion of copper-tin and coppertin-zinc alloys for three ranges of temperature. The effect of different contents of tin and lead in leaded bronzes is shown in a similar manner
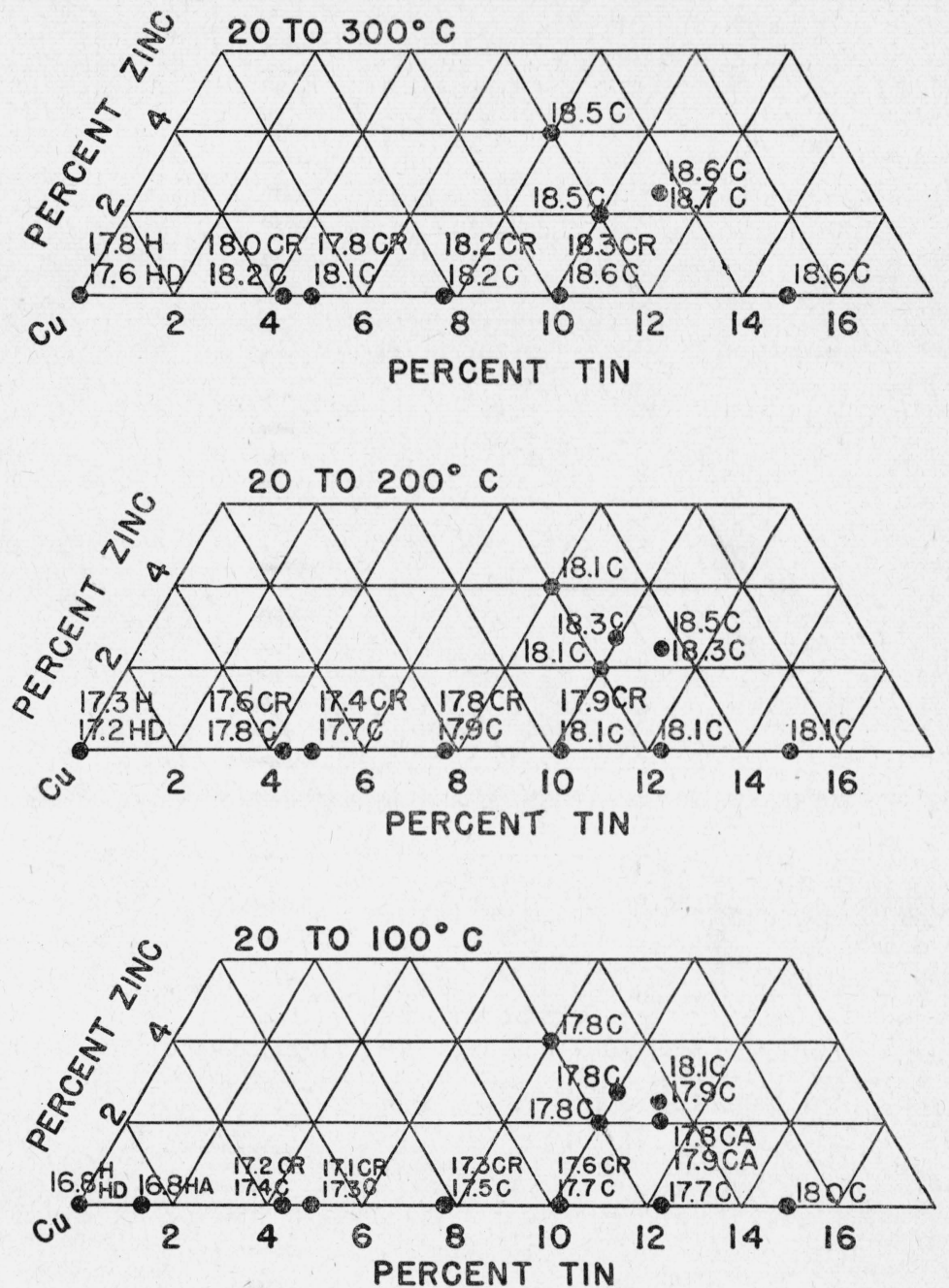

Figure 5.-Portions of triangular diagrams indicating the effects of composition on

the coefficints of expansion (in millionths per degree centigrade) of copper-tin and copper-tin-zinc alloys.

$$
\begin{aligned}
C & =\text { Cast. } \\
C A & =\text { Cast and annealed. } \\
C R & =\text { Cold-rolled. }
\end{aligned}
$$

$H=$ Hot-rolled.

$H A=$ Hot-rolled and annealed. $H D=$ Hot-rolled and drawn.

in figures 6 and 7 . These figures are based on the data in table 2 and previously published results of the author $[6,7,9]$. These diagrams show, in general, that the coefficients of expansion of the bronzes increase as the content of these addition elements is increased. 


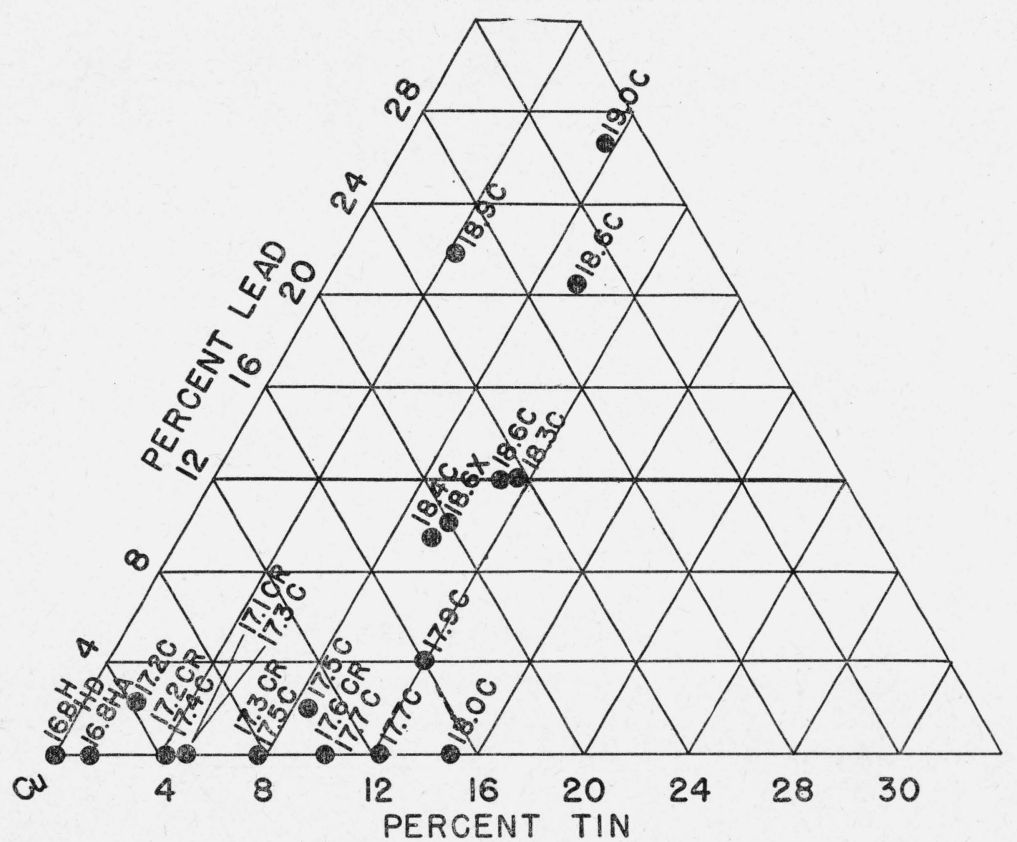

FIGURE 6.-Portion of triangular diagram indicating the effects of composition on the coefficients of expansion (in millionths per degree centigrade) of copper-tin and copper-tin-lead alloys between $20^{\circ}$ and $100^{\circ} \mathrm{C}$.

$\begin{aligned} C & =\text { Cast. } \\ C R & =\text { Cold-rolled. } \\ H & =\text { Hot-rolled. }\end{aligned}$

$H A=$ Hot-rolled and annealed. $H D=$ Hot-rolled and drawn. $X=$ Treatment unknown. 


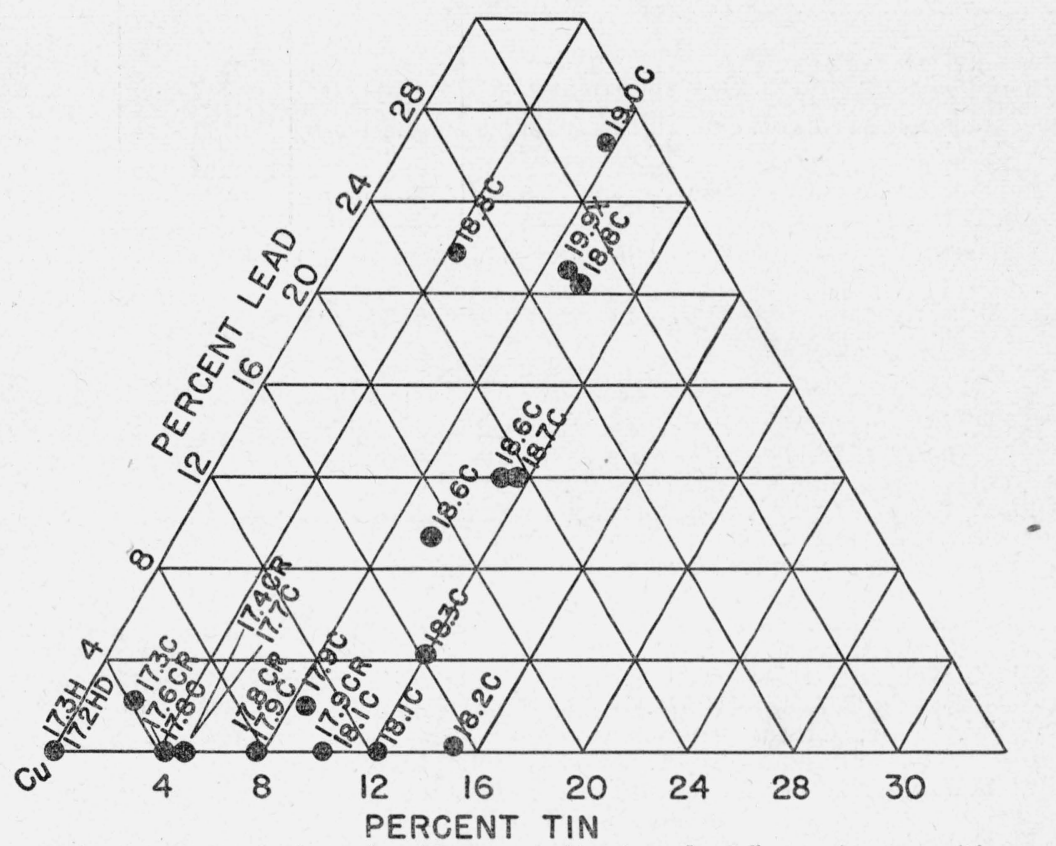

FIGURE 7.-Portion of triangular diagram indicating the effects of composition on the coefficients of expansion (in millionths per degree centigrade) of copper-tin and copper-tin-lead alloys between $20^{\circ}$ and $200^{\circ} \mathrm{C}$.

$$
\begin{aligned}
C & =\text { Cast. } & H D & =\text { Hot-rolled and drawn. } \\
C R & =\text { Cold-rolled. } & X & =\text { Treatment unknown. } \\
H & =\text { Hot-rolled. } & &
\end{aligned}
$$


The limiting coefficients of expansion of different bronzes for three temperature ranges are given in table 3.

In cases where comparison was possible, the data presented in this paper were found to be in good agreement with the results of other investigators.

TABLE 3.-Ranges of coefficients of linear expansion a of various bronzes

\begin{tabular}{|c|c|c|c|}
\hline \multirow{2}{*}{ Alloys } & \multicolumn{3}{|c|}{$\begin{array}{l}\text { A verage coefficients of expansion per degree } \\
\text { centigrade }\end{array}$} \\
\hline & $20^{\circ}$ to $100^{\circ} \mathrm{C}$. & $20^{\circ}$ to $200^{\circ} \mathrm{C}$. & $20^{\circ}$ to $300^{\circ} \mathrm{C}$. \\
\hline $\begin{array}{l}\text { Copper-tin (0 to } 15.0 \% \text { tin) } \\
\text { Copper-tin-zinc }(8 \text { to } 12 \% \text { tin, } 2 \text { to } 4 \% \text { zinc) } \\
\text { Copper-tin-lead (2.0 to } 11.6 \% \text { tin, } 2.1 \text { to } 26.6 \% \text { lead) } \\
\text { Copper-tin-zinc-lead ( } 5.0 \text { to } 6.7 \% \text { tin, } 2 \text { to } 5.1 \% \text { zinc, } 1.5 \text { to } \\
7.5 \% \text { lead). }\end{array}$ & $\begin{array}{c}\times 10^{-6} \\
16.8 \text { to } 18.0 \\
17.8 \text { to } 18.1 \\
17.2 \text { to } 19.0 \\
17.8 \text { to } 18.1\end{array}$ & $\begin{array}{l}\times 10^{-6} \\
17.2 \text { to } 18.2 \\
18.1 \text { to } 18.5 \\
17.3 \text { to } 19.9 \\
18.1 \text { to } 18.4\end{array}$ & $\begin{array}{c}\times 10^{-8} \\
17.6 \text { to } 18.6 \\
18.5 \text { to } 18.7 \\
\end{array}$ \\
\hline $\begin{array}{l}\text { Copper-aluminum ( } 7.3 \text { to } 10 \% \text { aluminum }) \\
\text { Copper-silicon b (3.0 to } 4.4 \% \text { silicon) }\end{array}$ & $\begin{array}{r}16.2 \text { to } 17.1 \\
17.2^{\circ} \text { to } 17.4\end{array}$ & $\begin{array}{r}16.3 \text { to } 17.3 \\
17.5^{\circ} \text { to } 17.8\end{array}$ & $\begin{aligned} 16.8 \text { to } 18.2 \\
18.0^{\circ} \text { to } 18.1\end{aligned}$ \\
\hline
\end{tabular}

a Data from previous publications by the author $[6,7,9]$ were also used in the preparation of this table. b Contain $1 \%$ manganese.

- Coefficients of contraction of a cast $4.4 \%$ silicon bronze were found to be $16.3 \times 10^{-6}, 17.3 \times 10^{-6}$, and $17.9 \times 10^{-6}$ for the ranges $100^{\circ}$ to $20^{\circ} \mathrm{C}, 200^{\circ}$ to $20^{\circ} \mathrm{C}$, and $300^{\circ}$ to $20^{\circ} \mathrm{C}$, respectively.

\section{REFERENCES}

[1] H. Fizeau, Tableau des dilatations par la chaleur de divers corps simples métalliques, ou non métalliques. et de quelques composés hydrogénés du carbone, Compt. rend. 68, 1125 (1869).

[2] R. Benoît, Comparaisons de règles métriques et mesures de dilatations, J. phys. 8, $451(1889)$.

[3] Dittenberger and Gehrcke, Die Thätigkeit der Physikalisch-Technischen Reichsanstalt im Jahre 1901, p. 112. (See also W. Dittenberger, Leber die Ausdehnung von Eisen, Kupfer, Aluminium, Messing und Bronze in hoher Temperatur, Z. Ver. deut. Ing. 46, 1532 (1902).)

[4] F. Henning, Über die Ausdehnung fester Körper bei tiefer Temperatur, Ann. Physik 32', 631 (1907).

[5] W. Bein, Ausdehnungsbestimmungen am Abbe-Fizeauschen Dilatometer, Verhandl. deut. physik. Ges. 14, 1097 (1912).

[6] P. Hidnert, Thermal expansion of copper and some of its important industrial alloys, BS Sci. Pap. 17, 91 (1922) S410.

[7] P. Hidnert, Thermal expansion of copper alloys, Phys. Rev. 39, 551 (1932).

[8] R. A. Wilkins, Herculoy, A copper-silicon-tin-zinc alloy, Metals \& Alloys 4, 123 (1933).

[9] P. Hidnert, Thermal expansion of bearing bronzes, BS J. Research 12, 391 (1934) RP665.

[10] G. Koiso, K. Kusumoto, and M. Yata, Some corrosion-resistant wrought aluminum bronzes of high strength, Tetsu-to-Hagane 26, 537 (1940). Abstracted in Chem. Abstracts 35, 422 (1940).

[11] A. W. Gray, A new type of apparatus for measuring linear expansion, Phys. Rev. 34, 139 (1912).

[12] A. W. Gray, New methods for displacement measurements and temperature uniformity applied to the determination of linear expansivity, J. Wash. Acad. Sci. 2, 248 (1912).

[13] W. Souder and P. Hidnert, Measurements on the thermal expansion of fused silica, BS Sci. Pap. 21, 1 (1926-27) S524.

[14] H. Le Chatelier, Sur la dilatation des métaux aux températures elevées, Compt. rend. 108, 1096 (1889).

Washington, October 22, 1942. 
NATIONAL BUREAU OF STANDARDS,

WASHINGTON, D. C.

Send me the Mathematical Tables marked $\mathrm{X}$ below. I enclose remittance ${ }^{1}$ to cover the cost.

\begin{tabular}{|c|c|c|c|c|}
\hline \multirow[b]{2}{*}{ Mark X } & \multirow[b]{2}{*}{ Title of publication } & \multicolumn{2}{|c|}{ Price } & \multirow[b]{2}{*}{ Amount enclosed } \\
\hline & & $\begin{array}{l}\text { United States and } \\
\text { its possessions, } \\
\text { and countries ex- } \\
\text { tending franking } \\
\text { privilege }\end{array}$ & Other countries & \\
\hline 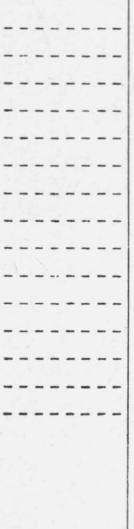 & $\begin{array}{l}\text { MT1. Table of the first ten powers of the integers from } 1 \text { to } \\
\text { MT2. Tables of the exponential function } e^{x} \\
\text { MT3. Tables of circular and hyperbolic sines and cosines for radian arguments } \\
\text { MT4. Tables of sines and cosines for radian arguments } \\
\text { MT5. Tables of sine, cosine, and exponential integrals, volume I } \\
\text { MT6. Tables of sine, cosine, and exponential integrals, volume II } \\
\text { MT7. Table of natural logarithms, volume I } \\
\text { MT8. Tables of probability functions, volume I } \\
\text { MT9. Table of natural logarithms, volume II } \\
\text { MT10. Table of natural logarithms, volume III } \\
\text { MT11. Tables of moments of inertia and section moduli } \\
\text { MT12. Table of natural logarithms, volume IV } \\
\text { MT13. Table of sine and cosine integrals } \\
\text { MT14. Tables of probability functions, volume II } \\
\text { MT15. The hypergeometric and Legendre functions with applications to integral } \\
\text { equations of potential theory }\end{array}$ & $\begin{array}{l}\$ 0.50 \\
2.00 \\
2.00 \\
2.00 \\
2.00 \\
2.00 \\
2.00 \\
2.00 \\
2.00 \\
2.00 \\
2.00 \\
2.00 \\
2.00 \\
2.00 \\
2.00\end{array}$ & $\begin{array}{r}\$ 0.65 \\
2.50 \\
2.50 \\
2.50 \\
2.50 \\
2.50 \\
2.50 \\
2.50 \\
2.50 \\
2.50 \\
2.50 \\
2.50 \\
2.50 \\
2.50 \\
\text { 2. } \\
\text { 2. } \\
\end{array}$ & 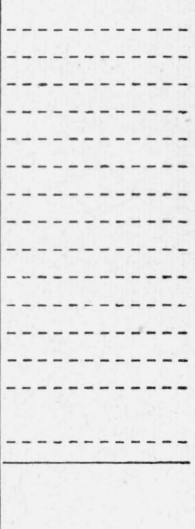 \\
\hline
\end{tabular}

${ }^{1}$ Remittance should be in form oi post-office money order, or check, and made payable to the order of the "National Bureau of Standards" in United States currency.

Send to

Number and Street

City and State 


\section{MATHEMATICAL TABLES}

Attention is invited to a series of publications which is being prepared by the Project for the Computation of Mathematical Tables conducted by the Federal Works Agency, Work Projects Administration for the City of New York under the sponsorship of the National Bureau of Standards. To date, 14 tables have been made available through the National Bureau of Standards. These are listed below:

There is also included in this list a publication on the hypergeometric and Legendre functions (MT15), prepared by the Bureau.

MT1. Table or the First Ten Powers of the Integrrs From 1 to 1000:

(1938) VIII+80 pages; heavy paper cover. 50 cents.

MT2. Tables of the Exponential Function $e^{x}$ :

The ranges and intervals of the argument and the number of decimal places in the entries are given below:

$\begin{array}{ccc}\text { Range of } x & \text { Interval of } x & \text { Decimals given } \\ -2.5000 \text { to } 1.0000 & 0.0001 & 18 \\ 1.0000 \text { to } 2.5000 & .0001 & 15 \\ 2.500 \text { to } 5.000 & .001 & 15 \\ 5.00 \text { to } 10.00 & .01 & 12\end{array}$

(1939) XV + 535 pages; bound in buckram, $\$ 2.00$.

MT3. Tables of Circular and Hyperbolic Sines and Cosings for Radian Arguments:

Contains 9 decimal place values of $\sin x, \cos x, \sinh x$ and $\cosh x$ for $x$ (in radians) ranging from 0 to 2 at intervals of 0.0001 .

(1939) XVII+405 pages; bound in buckram, $\$ 2.00$.

MT4. Tables of Sines and Cosines for Radian Arguments:

Contains 8 decimal place values of sines and cosines for radian arguments ranging from 0 to 25 at intervals of 0.001 .

(1940) XXIX+275 pages; bound in buckram, $\$ 2.00$.

MT5. Tables of Sine, Cosine, and Exponential Integrals, Volume I:

Values of these functions to 9 places of decimals from 0 to 2 at intervals of 0.0001 .

(1940) XXVI + 444 pages; bound in buckram, $\$ 2.00$.

MT6. Tables of Sine, Cosine, and Exponential Integrats, Volume II:

Values of these functions to 9,10 , or 11 significant figures from 0 to 10 at intervals of 0.001 with auxiliary tables.

(1940) XXXVII+225 pages; bound in buckram, $\$ 2.00$.

\section{MT7. Table or Natural Logarithms, Volume I:}

Logarithms of the integers from 1 to 50,000 to 16 places of decimals.

(1941) XVIII + 501 pages; bound in buckram, $\$ 2.00$.

MT8. Tables of Probability Functions, Volume I:

Values of these functions to 15 places of decimals from 0 to 1 at intervals of 0.0001 and from 1 to 5.6 at intervals of 0.001 .

(1941) XXVIII+ 302 pages; bound in buckram, $\$ 2.00$.

[Continued on p. 4 of cover] 


\section{[Continued from p. 3 of cover]}

\section{MT9. Table of Natural Logarithms, Volume II:}

Logarithms of the integers from 50,000 to 100,000 to 16 places of decimals.

(1941) XVIII + 501 pages; bound in buckram, $\$ 2.00$.

MT10. Table of Natural Logarithm, Volume III:

Logarithms of the decimal numbers from 0.0001 to 5.0000 , to 16 places of decimals.

(1941) XVIII+ 501 pages; bound in buckram, $\$ 2.00$.

MT11. Tabies or the Moments of Inertia and Section Moduli of Ordinary Anglgs Channels, and Bulb Angles with Certain Plate Combinations:

(1941) XIII+197 pages; bound in green cloth. $\$ 2.00$.

MT12. Table of Natural Logarithm, Volume IV:

Logarithms of the decimal numbers from 5.0000 to 10.0000 , to 16 places of decimals.

(1941) XXII+506 pages; bound in buckram, $\$ 2.00$.

MT13. Table of Sine and Cosine Intrgrals for Arguments from 10 to 100:

(1942) XXXII+ 185 pages; bound in buckram, $\$ 2.00$.

MT14. Tables of Probability Functions, Volume II:

Values of these functions to 15 places of decimals from 0 to 1 at intervals of 0.0001 and from 1 to 7.8 at intervals of 0.001 .

(1942) XXI+344 pages; bound in buckram, $\$ 2.00$.

MT15. The hypergeometric and Legendre functions with applications to integral equations of potential theory. By Chester Snow, National Bureau of Standards. Reproduced from original handwritten manuscript.

(1942) VII + 319 pages; bound in heavy paper cover. $\$ 2.00$.

Payment is required in advance. Make remittance payable to the "National Bureau of Standards", and send with order, using the blank form facing page 3 of the cover.

The prices are for delivery in the United States and its possessions and in countries extending the franking privilege. To other countries the price of MT1 is 65 cents; that of MT2 to MT15, inclusive, is $\$ 2.50$ each; remittance to be made payable in United States currency.

Copies of these publications have been sent to various Government depositories throughout the country, such as public libraries in large cities, and colleges and universities, where they may be consulted.

A mailing list is maintained for those who desire to receive announcements regarding new tables as they become available. A list of the tables it is planned to publish will be sent on request. 